\title{
ANALYSIS OF MODERATE ALTITUDE INDUCED CHANGES ON THE SYNTHESIS OF ERYTHROPOIETIN
}

\author{
M. ELAMARAN ${ }^{\mathrm{a}, *}$ \\ ${ }^{a}$ Assistant Professor, Department of Physical Education \& Sports Sciences, Annamalai \\ University, Annamalai Nagar, Chidambaram - 608 002, Tamil Nadu, India. \\ *Corresponding Author Ph: 0 9994467052; Email: maran_1974@yahoo.co.in
}

\section{DOI: $10.26524 / 1348$}

\begin{abstract}
The present investigation is proposed to elucidate the changes on erythropoietin levels induced by the exposure to Ootacamund. For this purpose, fifteen male handball players in the age group of 20 to 25 years were selected as subjects from Annamalai University, during their competitive season. The erythropoietin was selected as dependent variable and it was appraised using procedures and instruments of scientific standards at Chidamabaram (sea level) and during the sixth hour of acute exposure to Ootacamund (moderate altitude). To compare the changes on erythropoietin at moderate altitude with that of the sea level, „te test was used. The analysis of data revealed that there is a significant amplification on erythropoietin in respon se to moderate altitude exposure, since the obtained ,t" ratio for 14 degrees of freedom is 11.233 ( $\mathrm{p}<0.05$. Exposure to Ootacamund had an affirmative impact on erythropoietin. This result suggests that exposure to Ootacamund is capable of inducing significant changes on erythropoietin and thereby enhanced aerobic endurance performance of sportsperson.
\end{abstract}

Keywords: Altitude, Erythropoietin, sea level, aerobic performance

\section{Introduction}

Exposure to high altitude causes the body to acclimatise to the lower level of oxygen available in the atmosphere. Acclimatization to high altitude includes a number of physiological and hematologic adaptations that theoretically should improve $\mathrm{O}_{2}$ transport to skeletal muscles during exercise [1].

Reduced arterial $\mathrm{PO}_{2}$ at altitude stimulates an increase in the total number of red blood cells, a condition termed polycythemia. The erythrocyte-stimulating hormone erythropoietin (EPO), synthesized and released primarily from the kidneys in response to localized arterial hypoxia, initiates red blood cell formation within 15 hours after altitude ascent. In the weeks that follow, erythrocyte production in the marrow of the long bones increases considerably and remains elevated throughout the altitude stay [2]. Valuable increases in hemoglobin also occur in proportion to the increased erythrocyte production. Up to a point, the more blood cells an athlete have, the more oxygen he can deliver to his muscles. The increased red blood cells, resulting in higher hemoglobin values, ensure better working capacity. Higher the altitude, greater the stimulus will be to produce extra red cells. However, the exact magnitude of the barometric pressure reduction in any geographical location depends on the combination of elevation, latitude, season and weather.

Ootacamund is a hill station in south India at an altitude of 2204 metres above mean sea level and at the latitude of $11^{\circ} 24^{\prime}$ north, necessitates to study the effect of exposure to Ootacamund on the hormone erythropoietin, since no such investigation has been carried out in evaluating the erythropoietin secretion in such a geographical location. This investigation would facilitate in understanding the potential benefits of exposure to Ootacamund for the purpose of enhancing sports performance. Thereby, the purpose of this study is to elucidate the changes on erythropoietin levels induced by the exposure to Ootacamund.

\section{Methodology \\ Subjects and variables}

Fifteen male handball players, those represented Annamalai University in the All India Inter University Handball Tournament volunteered as subjects as part of the expedition to an altitude of 2,204 metres above mean sea level. The age and weight of the selected subjects averaged $21.80 \pm 2.01 \mathrm{yr}$ and $64.6 \pm 5.18 \mathrm{~kg}$ respectively, and they were recruited for the purpose of the study with their written informed consent.

The independent variables considered in this study were (i) Sea Level (Chidambaram), 5.75 metres above mean sea level and (ii) Moderate Altitude (Ootacamund), 2,200 metres above mean sea level. The erythropoietin was the only dependent variable selected for this paper was assessed using standard procedures at sea level and during the sixth hour of acute expos ure to moderate altitude. The instruments involved in blood collection and testing were confirmed to scientific standard using Quantikine IVD kit and ELISA reader.

The initial collection of blood was carried out the day before departure in Chidambaram (5.75 m above MSL). The subjects were transported by automobile from Chidambaram to Ootacamund, a trip of about 10 hours. The second test was conducted at the sixth hour of exposure in Ootacamund (2,204m above MSL). The collection of blood was carried out at 08.00 hours at both the venues, to avoid diurnal variations. A phlebotomist was recruited for the process of obtaining samples of venous 
blood from the antecubital vein by using a syringe. The serum was harvested and stored in labeled Eppendorf tubes, which were frozen at $-20^{\circ} \mathrm{C}$ until hormone analysis was conducted.

\section{Experimental Design and Statistical Techniques}

Random group design involving fifteen subjects was used for the purpose of expounding the changes in the synthesis and release of erythropoietin in response to moderate altitude induced decrease in the partial pressure of inspired oxygen. To determine the significant difference existing between the data collected at sea level and moderate altitude on selected dependent variables , „te test was used. The level of significance was accepted at $P<0.01$.

Results in table II.

The descriptive analysis and „„te ratio of data collected on erythropoietin at sea level and moderate altitude is presented

Table III: Computation of Data on Erythropoietin

\begin{tabular}{|c|c|c|c|c|c|c|c|c|}
\hline & $\mathrm{N}$ & Mean & $\begin{array}{c}\text { Std. } \\
\text { Deviation }\end{array}$ & $\begin{array}{c}\text { Difference } \\
\text { between } \\
\text { Mean }\end{array}$ & $\begin{array}{c}\text { Std. Error of } \\
\text { Difference } \\
\text { between Mean }\end{array}$ & ,te ratio & df & Sig. \\
\hline $\begin{array}{c}\text { At } \\
\text { Sea level }\end{array}$ & 15 & 7.38 & 1.472 & 1.64 & 0.036 & 11.233 & 14 & .000 \\
\hline At Altitude & 15 & 9.02 & 1.645 & & & & & \\
\hline
\end{tabular}

The findings of the study shows that there is a significant amplification on erythropoietin in response to moderate altitude exposure, since the obtained , „te ratio for 14 degrees of freedom is $11.233(\mathrm{p}<0.05)$. The finding of the study reveals that there was an affirmative impact on erythropoietin synthesis.

\section{Discussion}

The present finding is in agreement with the findings of Boning et al., (2004) that erythropoietin was little increased in a moderate altitude of $2600 \mathrm{~m}$, while Richalet et al., (1994) pronounced an initial sharp increase in erythropoietin [3, 4]. In addition Eckardt et al., (1989) were evident that the concentration of EPO in blood increases 90 to 120 min after reduction of the inspiratory $\mathrm{PO}_{2}$, besides the EPO rises progressively during the first 24-48 hours [5]. Gunga et al., (2003) and Stray-Gundersen, Chapman \& Levine (2001) stated that erythropoietin concentration almost doubled after one night at moderate altitude [6, 7].

\section{Conclusions}

The present investigation displays that acute exposure to Ootacamund induces significant changes on erythropoietin in response to reduced partial pressure of oxygen and furthermore forms the basis for stimulating erythrocytes and in the formation of red blood cells in order to increase the oxygen transport capacity of the blood. This reveals that altitude training at Ootacamund would enhance the aerobic endurance capacity of sportspersons and needs to be explored further for substantiating its efficacy.

\section{REFERENCES}

[1] B.D. Levine, J. Stray-Gundersen, "Living high-training low": Effect of moderate-altitude acclimatization with lowaltitude training on performance, Journal of Applied Physiology, 83 (1997) 102-12.

[2] B.M. Groves, J.T. Reeves, J.R. Sutton, P.D. Wagner, A. Cymerman, M.K. Malconian, P.B. Rock, P.M. Young, C.S. Houston, Operation Everest II: elevated high-altitude pulmonary resistance unresponsive to oxygen, Journal of Applied Physiology, 63 (1987) 521-30.

[3] D. Böning, E. Cristancho, M. Serrato, O. Reyes, M. Mora, L. Coy, J. Rojas, Hemoglobin Mass and Peak Oxygen Uptake in Untrained and Trained Female Altitude Residents. International Journal of Sports Medicine, 25 (2004) 5618.

[4] J.P. Richalet, J.C. Souberbielle, A.M. Antezana, M. Déchaux, J.L. Le Trong, A. Bienvenu, F. Daniel, C. Blanchot, J. Zittoun, Control of erythropoiesis in humans during prolonged exposure to the altitude of $6,542 \mathrm{~m}$. American Journal of Physiology, 266 (1994) R756-64.

[5] K.U. Eckardt, U. Boutellier, A. Kurtz, M. Schopen, E.A. Koller, C. Bauer, Rate of erythropoietin formation in humans in response to acute hypobaric hypoxia, Journal of Applied Physiology, 66 (1989) 1785-8.

[6] H.C. Gunga, D. Fries, E. Humpeler, K. Kirsch, L.E. Boldt, E. Koralewski, B. Johannes, A. Klingler, M. Mittermayr, L. Röcker, B. Yaban, C. Behn, W.E.B. Jelkmann, W. Schobersberger, Austrian Moderate Altitude Study (AMAS 2000) fluid shifts, erythropoiesis, and angiogenesis in patients with metabolic syndrome at moderate altitude (congruent with 1700 m). Europian Journal of Applied Physiology, 88 (2003) 497-505.

[7] J. Stray-Gundersen, R.F. Chapman B.D. Levine, "Living high-training low" altitude training improves sea level performance in male and female elite runners, Journal of Applied Physiology, 91 (2001) 1113-20. 